DOI https://doi.org/10.30525/978-9934-26-046-9-7

\title{
СТАТИСТИЧНІ МЕТОДИ КОНТРОЛЮ ЯКОСТІ МОЛОЧНОЇ ПРОДУКЦЇ̈
}

\author{
Криворучко О. В.
}

доктор технічних наук, професор, завідувач кафедри інженерії програмного забезпечення та кібербезпеки

Київський національний торговельно-економічний університет м. Київ, Украӥна

\section{Костюк Ю. В.}

асистент кафедри інженерії програмного забезпечення та кібербезпеки

Київський національний торговельно-економічний університет м. Київ, Украӥна

Самойленко Ю. О. кандидат технічних наук, доцент кафедри автоматизаиії та комп 'ютерних технологій систем управління Національний університет харчових технологій м. Київ, Украӥна

В умовах сьогодення економічного розвитку харчової промисловості на перший план висуваються проблеми збільшення ефективності функціонування підприємств за рахунок підвищення якості випускаємої продукції. Задля вирішення даних питань виникає необхідність у використанні новітніх підходів, що пов'язані у забезпечені ліній виробництва сучасними засобами неперервного автоматичного контролю, регулювання і керування на основі ефективних інформаційноінтелектуальних технологій.

Складність технологічних процесів у харчовій промисловості зумовлена тим, що більшість сировини для виробництва є складними i неоднорідними багатокомпонентними сумішами (наприклад, молочна промисловість), які залежать від багатьох факторів, починаючи від самого складу сировини до фізико-хімічних властивостей продукції на проміжних та кінцевих стадіях виробництва і т.п. Все це призводить 
до коливань параметрів самого технологічного процесу і якості кінцевого продукту [1-3].

Фактори варіативності технологічного процесу можна поділити на дві групи. Першу групу формують загальні причини, які можуть бути пов'язані безпосередньо із виробничим процесом, а саме: обладнанням, персоналом чи сировиною. Такі варіативності усуваються лише за допомогою керівництва. Другу групу формують спеціальні причини, які можуть бути пов'язані із помилками оператора-технолога, порушеннями технологічного режиму або змінами налаштувань. Такі порушення вирішуються за допомогою спеціалістів, які беруть безпосередню участь у цьому процесі. Всі ці фактори впливають на управлінські рішення, які грунтуються на моніторингу та діагностиці ситуацій: збору, обробки та аналізу інформації з використанням статистичних методів [4].

Основним завданням статистичних методів контролю $є$ забезпечення виробництвом, придатної до вживання продукції і надання корисних послуг 3 найменшими витратами за рахунок вимірювання та аналізу коливань параметрів процесу, що в подальшому дозволяє їх зменшити та знизити появу дефектів.

Два основних поняття контролю якості - це вимірювання контрольованих параметрів і їх розподіл, який засновано на тому, що немає двох абсолютно однакових за величиною параметрів в одних і тих же виробів; в міру того, як вимірювання стають все більш точними, в результатах вимірювань параметра виявляються невеликі розбіжності.

Серед статистичних методів контролю якості найбільш поширені так звані сім інструментів контролю якості [4]:

1) діаграма Парето (Pareto Diagram) - графічний метод ранжування факторів;

2) причинно-наслідкова діаграма Ісікави (Cause and Effect Diagram);

3) контрольна карта (Contrat Chait);

4) гістограма (Histogram);

5) діаграма розкиду (Scatter Diagram);

6) метод розшарування (Stratification);

7) контрольні листки.

У своїй сукупності ці методи утворюють ефективну систему методів контролю та аналізу якості. Дані методи можуть застосовуватися у будь-якій послідовності, в будь-якому поєднанні, їх можна розглядати і як цілісну систему, і як окремі інструменти аналізу. 
Отже, статистичний контроль якості - це застосування статистичних принципів, методів і прийомів на всіх стадіях виробництва, направлене на своєчасне виявлення порушень технологічного процесу до того часу, коли може виникнути дефект продукції. За допомогою статистичних методів можливо встановити також і причини таких порушень.

\section{Література:}

1. Криворучко О.В, Костюк Ю.О., Самойленко Ю. О. Система підтримки прийняття рішень з управління якістю. The driving force of science and trends in its development: I International Scientific and Theoretical Conference. (Coventry, United Kibgdom, 29 January 2021). Coventry, 2021. Vol. 3. Pp. 22-23.

2. Федюкин В.К., Дурнев В.Д., Лебедев В.Г. Методы оценки и управления качеством промышленной продукции. Учебник. Изд. 2-е перераб. и доп. М.: ИИД «Филинъ», Рилант, 2001. 328 с.

3. Безродна С. М. Управління якістю: навч. посіб. Чернівці: ПВКФ «Технодрук», 2017. $174 \mathrm{c}$.

4. Клячкин В.Н. Статистические методы в управлении качеством: компьютерные технологии: учеб. пособие. М.: Финансы и статистика, ИНФРА-М, 2009. 304c. 